\title{
EFFECT OF BACLOFEN ON LIQUID AND SOLID GASTRIC EMPTYING IN RATS
}

\author{
Edgard Ferro COLLARES ${ }^{1,2}$ and Adriana Mendes VINAGRE ${ }^{2}$
}

\begin{abstract}
Context - Gamma-aminobutyric acid (GABA) is a potent inhibitory neurotransmitter. There is evidence that GABA receptors located in the dorsal complex and in afferent fibers of the vagus nerve participate in the control of gastrointestinal motility. Objectives - To assess the intracerebroventricularly (ICV) and intravenously (IV) effect of baclofen, a GABA $\mathrm{B}_{\mathrm{B}}$ receptor agonist, on liquid and solid gastric emptying in rats. Methods - Adult male Wistar rats weighing 250-300 $\mathrm{g}(\mathrm{n}=6-8$ animals) were used. Gastric emptying of liquid test meals labeled with phenol red was evaluated by the determination of percent gastric retention ( $\% \mathrm{GR}) 10$ and 15 min after orogastric administration of saline and 10\% glucose meals, respectively. Baclofen was injected ICV ( 1 and $2 \mu \mathrm{g} / \mathrm{animal})$ through a tube implanted into the lateral ventricle of the brain and was injected IV (1 and $2 \mathrm{mg} / \mathrm{kg})$ into a tail vein. The gastric emptying of liquid was determined 10 or $30 \mathrm{~min}$ after ICV and IV baclofen administration, respectively. The gastric emptying of the solid meal was assessed by the determination of percent gastric retention $2 \mathrm{~h}$ after the beginning of the ingestion of the habitual ratio by the animal, consumed over a period of $30 \mathrm{~min}$. Baclofen was administered ICV (1 and $2 \mu \mathrm{g} / \mathrm{animal})$ or IV ( 1 and $2 \mathrm{mg} / \mathrm{kg}$ ) immediately after the end of the ingestion of the solid meal. The control groups received vehicle (sterile saline solution) ICV or IV. Results - The group of animals receiving baclofen ICV ( $2 \mathrm{mg} / \mathrm{animal})$ presented a significantly lower $(P<0.05$, Tukey test) \%GR (mean $\pm \mathrm{SEM})$ of the saline $(18.1 \pm 2.5 \%)$ compared to control $(33.2 \pm 2.2 \%)$. In the group receiving the drug IV, the gastric retention of the same test meal did not differ from control. ICV and IV administration of baclofen had no effect on the gastric emptying of the $10 \%$ glucose solution compared to control. ICV administration of 1 or $2 \mu \mathrm{g}$ baclofen/animal significantly increased the gastric retention of the solid test meal $(57.9 \pm 6.5 \%$ and $66.6 \pm 6.3 \%$, respectively) compared to control $(35.1 \pm 4.4 \%)$. The same phenomenon was observed only with the IV dose of $2 \mathrm{mg} / \mathrm{kg}(71.9 \pm 2.6 \%)$ compared to control (52.7 $\pm 2.8 \%)$. Conclusions - Baclofen administered: 1. ICV ( $2 \mu \mathrm{g} / \mathrm{animal})$, but not IV, increased gastric emptying of a non-caloric isotonic liquid test meal (saline); 2 . when administered ICV or IV, it had no effect of gastric emptying of a $10 \%$ glucose solution; 3 ) when administered ICV (1 and $2 \mu \mathrm{g} / \mathrm{animal})$ and IV (2 $\mathrm{mg} / \mathrm{kg}$ ) it delayed the gastric emptying of the solid meal.
\end{abstract}

HEADINGS - Gastric emptying. Baclofen. Rats.

\section{INTRODUCTION}

Gastric emptying (GE) is the transfer of the gastric content to the small intestine as the result of stimulating and inhibiting mechanisms that control the motor activity of the stomach, pylorus and duodenum. Under physiological conditions, GE takes place in an adequate manner according to the digestion and absorption conditions occurring in the small intestine ${ }^{(44)}$. From a functional viewpoint, the stomach is divided into a proximal or oral region (fundus and approximately one-third of the gastric body) and into a distal or caudal region (remainder of the gastric body and antrum) ${ }^{(15,43,44)}$.

Gastric tonus reflects variations in the tonic contractions of the proximal stomach, which is responsible for the accommodation of the food bolus and, in part, for the GE of liquid ${ }^{(15,43)}$. The tonus of this region is the result of the balance of stimulating (increasing) activities and of inhibitory (reducing) activities, with regulation largely dependent on the participation of the vagus nerve. In general, the reduction of gastric tonus reduces fluid $\mathrm{GE}^{(2)}$, whereas increased tonus by reduction of the gastric fundus is accompanied by increased liquid $\mathrm{GE}^{(10)}$. The distal stomach presents peristaltic activity and is largely responsible for solid food GE. By processes of 1. propulsion, 2. evacuation and retropulsion, 3. increased retropulsion and trituration, the solid fragments are reduced to an appropriate size for passing through the pylorus together with the liquid phase of the meal ${ }^{(15,43)}$. The pylorus is not a high pressure zone but it contracts independently, altering the resistance to flow between the stomach and duodenum ${ }^{(44)}$.

Gamma-aminobutyric acid (GABA) is the most important inhibitory neurotransmitter in the central nervous system (CNS), in which the $\mathrm{GABA}_{\mathrm{A}}, \mathrm{GABA}_{\mathrm{B}}$ and $\mathrm{GABA}_{\mathrm{C}}$ receptors have been identified ${ }^{(5,13,21,28)}$

'Departamento de Pediatria; ${ }^{2}$ Núcleo de Medicina e Cirurgia Experimental, Faculdade de Ciências Médicas, Universidade Estadual de Campinas - UNICAMP, Campinas, SP, Brazil. Correspondence: Prof. Edgard Ferro Collares -Department of Pediatrics, Faculty of Medical Sciences - University of Campinas-UNICAMP -13083-970, Campinas, São Paulo, Brazil. - E-mail: efcollares@hotmail.com 
The main effects of the activation of $\mathrm{GABA}_{\mathrm{B}}$, receptors, with membrane $\mathrm{G}_{\alpha i} / \mathrm{G}_{\alpha \mathrm{o}}$ proteins acting as the transducer system, are an increase in $\mathrm{K}^{+}$channel conductance and a decrease in $\mathrm{Ca}^{++}$channel conductance ${ }^{(6,13,28)}$.

In the postsynaptic location, the activation of $\mathrm{GABA}_{\mathrm{B}}$ receptors leads to a prolonged increase in the conductance of the $\mathrm{K}^{+}$channel, which is responsible for the generation of slow GABAergic inhibitory events in the $\mathrm{CNS}^{(14,28)}$. In the presynaptic location, these receptors are involved in the regulation of transmitter release since the main effect of baclofen ( $\beta$-p-chlorophenyl-GABA), a $\mathrm{GABA}_{\mathrm{B}}$ receptor agonist, by reducing the conductance of $\mathrm{Ca}^{++}$channels, reduces the release of stimulating and inhibitory synaptic transmitters. This action of baclofen has been observed in a variety of synapses, with reduction, for example, of the release of noradrenaline, dopamine, acetylcholine, serotonin, glutamate, and aspartate ${ }^{(14,27)}$. It has also been observed that baclofen, in the presynaptic location, may act as an auto-receptor, reducing the release of GABA and thus reducing the postsynaptic inhibition determined by the activation of $\mathrm{GABA}_{\mathrm{A}}$ receptors ${ }^{(14,27,28)}$. The $\mathrm{GABA}_{\mathrm{B}}$ receptors in the brain are heterodimers of two subunits, i.e., $\mathrm{GABA}_{\mathrm{B}(1)}$ and $\mathrm{GABA}_{\mathrm{B}(2)}$. All known competitive agonist and antagonist receptors bind only to the $\mathrm{GABA}_{\mathrm{B}(1)}$ subunit, whereas the activation of protein $G$ is facilitated by the $\mathrm{GABA}_{\mathrm{B}(2)}$ subunit $^{(14)}$.

The dorsal vagal complex (DVC) is formed by the nucleus tractus solitarii (NTS) with neurons that receive information from afferent pathways, the area postrema and the dorsal vagal nucleus which contain the stimulatory and inhibitory motoneurons, whose axons represent the efferent pathways of the vagus nerve ${ }^{(45)}$.

In the rat, $\mathrm{GABA}_{\mathrm{B}}$ receptors have a presynaptic location in the afferent endings of the vagus nerve which project towards the NTS, with evidence existing that this nucleus is also located presynaptically ${ }^{(32)}$.

The use of GABA agonists and antagonists for receptors located in the DVC neurons has shown that this acid is involved in the control of gastrointestinal motility ${ }^{(3,19,38,46)}$. In particular, baclofen, through the vagus nerve, blocks the inhibitory stimuli on gastric secretion and increases gastric tonus and the frequency and amplitude of gastric and duodenal contractions $^{(1,16,18,31)}$.

In a study on the effect of baclofen on GE in mice, the drug, when administered intraperitoneally (IP) accelerated the GE of solids and delayed the GE of liquid, suggesting different effects on the proximal (liquid GE) and the distal (solid GE) stomach ${ }^{(40)}$. A surprising result was the reduction of $\mathrm{GE}$ of the liquid meal since, by increasing gastric tonus, baclofen would be expected to increase the GE of such a meal.

On the other hand, in our laboratory we observed that baclofen administered intracerebroventricularly (ICV) blocked the effect of delayed GE of a saline test meal induced by pyrazolone derivatives (dipyrone, 4-aminoantipyrine and antipyrine), administered intravenously (IV). No change, or only a slight but significant increased in GE of this test meal was observed in control animals ${ }^{(12,39,42)}$.
In view of these conflicting data, the objective of the present study was to assess in rats the effect of baclofen administered ICV and IV on GE of two liquid meals, a noncaloric isotonic one (saline solution), and a caloric one (10\% glucose solution) and of a caloric solid meal (ration habitually ingested by the animal).

\section{METHODS}

We used male Wistar rats weighing 250-300 g, adapted to laboratory conditions for at least 2 weeks. The experimental protocols used in the present study obeyed the recommendations of the Brazilian College of Animal Experimentation (COBEA). Before the surgical procedure for the implantation of a cannula in the lateral brain ventricle, the animal was sedated with an IP injection of thiopental, $75 \mathrm{mg} / \mathrm{kg}$. After the procedure or entry into the study, the animals were kept in individual cages with free access to ration and water.

At the time of the study, ( \pm )-baclofen (Sigma) was diluted in sterile physiological saline used as vehicle and the IV and ICV doses were those used in other studies ${ }^{(12,40)}$.

The same lot of autoclavable 6003 Nuvilab CR-1 ration for rats and mice was used as the solid test meal. The mean composition of the ration was as follows: $22 \%$ proteins, $42 \%$ carbohydrates, $4 \%$ fat, $10 \%$ mineral salts, $8 \%$ fibers, $1.4 \%$ calcium, $0.6 \%$ phosphorus, and $12 \%$ moisture. The ration was enriched with vitamins, mineral microelements and amino acids (lysine and methionine).

The GE of fluid and solid was determined in animals fasted for 24 hours (h) and receiving water ad libitum up to 30 minutes ( $\mathrm{min}$ ) before the studies.

In the study of the ICV effect of the drug, a stainless steel cannula $(22 \mathrm{G})$ was implanted into the right lateral ventricle of the brain 7 days before the experiment using previously established coordinates ${ }^{(12)}$.

\section{Gastric emptying of liquid test meals (saline and $10 \%$ glucose)}

The GE of the liquid meals was assessed in awake animals by the determination of percent gastric retention (GR) of $2 \mathrm{~mL} / 100 \mathrm{~g}$ animal weight of a saline or $10 \%$ glucose test meal labeled with phenol red at the concentration of $60 \mu \mathrm{g} /$ $\mathrm{mL}, 10$ and $15 \mathrm{~min}$, respectively, after administration by gavage using a standardized technique ${ }^{(9)}$. Two modifications were introduced in the procedure originally described: 1 . the reading for the determination of the concentration of the phenol red dye was performed with a spectrophotometer at $560 \mathrm{~nm}$ wavelength, and 2. animal sedation for sacrifice was performed with halothane.

\section{Effect of baclofen administered ICV}

An internal microinjection cannula $(28 \mathrm{G})$ connected to a $50 \mu \mathrm{L}$ Hamilton syringe by polyethylene tubing was used for ICV injection. The animals were divided into three groups, respectively injected ICV with $10 \mu \mathrm{L}$ vehicle $(0)$ or an equal volume of a solution containing 1 or $2 \mu \mathrm{g}$ baclofen, over a period of 30 seconds (s), with the system remaining 
connected for an additional $30 \mathrm{~s}^{(12)}$. The GE of the saline or $10 \%$ glucose test meal was assessed 10 min after the removal of the internal cannula.

\section{Effect of IV baclofen}

The animals were divided into three groups respectively injected IV through a caudal vein with $1 \mathrm{~mL} / \mathrm{kg}$ vehicle $(0)$ or an equal volume of a solution containing 1 or $2 \mathrm{mg} / \mathrm{kg}$ baclofen. The GE of the saline or $10 \%$ glucose test meal was assessed 10 min later.

\section{Gastric emptying of solid test meal}

The method of Langhans et al. ${ }^{(24)}$, with modifications made in our laboratory ${ }^{(36)}$ and described in detail below, was used for the determination of solid GE in awake animals.

Solid ration was previously dried. Four days before the experiment the ration was weighed in a beaker of known weight, placed in an oven at $70^{\circ} \mathrm{C}$ and left there up to 10 min before the beginning of the test. During this period the ration was weighed on at least four occasions until three stable weight measurements were obtained. The mean of these three weights minus the weight of the beaker was considered to be the dry weight.

For the test, the animal was transferred to a carefully washed and dried $30 \mathrm{~cm}$ long x $20 \mathrm{~cm}$ wide $\times 13 \mathrm{~cm}$ high individual propylene cage. After a $30 \mathrm{~min}$ period of adaptation to this cage, the ration was offered to the animal for a period of $30 \mathrm{~min}$. At the end of this time, the animals received the ICV or IV injection and was returned to its individual cage, where it was left without receiving water or ration up to $90 \mathrm{~s}$ before the pre-established time ( $2 \mathrm{~h}$ starting from the beginning of the offer of ration) for the determination of the GR of the ingested solid food test meal. The animal was then transferred to a glass bell saturated with halothane as an anesthetic and left there for $30 \mathrm{~s}$. The animal was then fixed to a flat surface and its abdomen was opened under inhalation anesthesia. After the stomach was visualized and the 2 pre-established hours had elapsed, the pylorus and the cardia were clamped and tied with cotton suture. The stomach was removed, washed on its outer surface, carefully dried with filter paper, and opened from the fundus to the great curvature. The gastric residue was transferred by washing the internal part of the stomach with distilled water to a previously weighed beaker marked with the number of the animal. The beaker containing the gastric residue was then placed in an oven in order to obtain the dry weight.

The uneaten ration remaining in the plastic cage was carefully transferred with a brush to the original beaker, which was placed in an oven until the dry weight was obtained.

The amount of ration ingested was calculated by subtracting the dry weight of the uneaten ration from the dry weight of the offered ration. Gastric retention, as percentage, was determined from the amount of ingested ration and the amount of solid gastric residue. The results are reported as $\%$ GR of the amount of ration ingested by each animal over a period of $30 \mathrm{~min}, 2 \mathrm{~h}$ after the beginning of ingestion.
The ingestion of ration, as $\mathrm{mg} / 100 \mathrm{~g}$ animal weight, was calculated from the total amount ingested within $30 \mathrm{~min}(\mathrm{mg})$ divided by fasting animal weight (g) x 100 .

\section{Effect of ICV baclofen}

The animals were divided into three groups respectively injected ICV with $10 \mu \mathrm{L}$ of vehicle (0) or an equal volume of a solution containing 1 or $2 \mu \mathrm{g}$ baclofen over a period of $30 \mathrm{~s}$, with the system remaining connected for an additional $30 \mathrm{~s}$. The drug was administered immediately after the end of the period of ration ingestion. This time of application was chosen to prevent a possible baclofen effect inhibiting the ingestion of ration, as observed in rats after IP injection of the drug ${ }^{(47)}$.

\section{Effect of IV baclofen}

The animals were divided into three groups respectively injected IV through a caudal vein with $1 \mathrm{~mL} / \mathrm{kg}$ vehicle $(0)$ or an equal volume of a solution containing 1 or $2 \mathrm{mg} / \mathrm{kg}$ baclofen. The drug was administered immediately after the end of the period of ration ingestion. This time of application was chosen for the same reason as when the drug was injected ICV.

At the end of the experiments, all animals were sacrificed and those who had received the drug by ICV injection received $10 \mu \mathrm{L} \mathrm{1 \%}$ Evans blue solution by the same route. The brain was removed and fixed in $10 \%$ formalin for $24 \mathrm{~h}$. After fixation, coronal brain sections were obtained and ICV injection was confirmed when the dye was visualized in the fourth ventricle.

The results of $\%$ GR are reported as mean \pm SEM. Data were analyzed statistically by ANOVA and pairs were compared by the Tukey test $(\propto=0.05)$.

\section{RESULTS}

\section{Gastric emptying of liquid test meals}

\section{Saline test meal. Effect of ICV and IV baclofen}

ICV administration of baclofen, $2 \mu \mathrm{g} /$ animal (Figure 1A), significantly reduced the GR of the saline test meal (mean $\pm \mathrm{SEM}=18.1 \pm 2.5 \%, \mathrm{n}=8)$ compared to control $(33.2 \pm$ $2.2 \%, \mathrm{n}=8$ ) indicating that administration of the drug in the CNS increased the GE of this type of meal. A nonsignificant reduction of GR was obtained with the baclofen dose of $1 \mu \mathrm{g}$ /animal $(24.2 \pm 3 \%, \mathrm{n}=8)$.

In contrast, IV administration of baclofen ( 1 and $2 \mathrm{mg} /$ $\mathrm{kg}$ ) had no effect on the GR of this test meal $(25.5 \pm 1.9 \%, \mathrm{n}$ $=8$ and $29.1 \pm 2.4 \%, \mathrm{n}=8$, respectively) compared to control $(31.8 \pm 1.3 \%, n=8)$ (Figure 1B).

Ten percent glucose meal. Effect of ICV and IV baclofen

ICV (Figure 2A) or IV (Figure 2B) administration of baclofen had no effect on the GE of a $10 \%$ glucose solution compared to control. In the group of animals receiving $2 \mu \mathrm{g}$ baclofen ICV, GR $(48.0 \pm 2.2 \%, \mathrm{n}=8)$ was significantly lower compared to animals that received $1 \mu \mathrm{g}$ by the same route $(56 \pm 2 \%, n=8)$. 


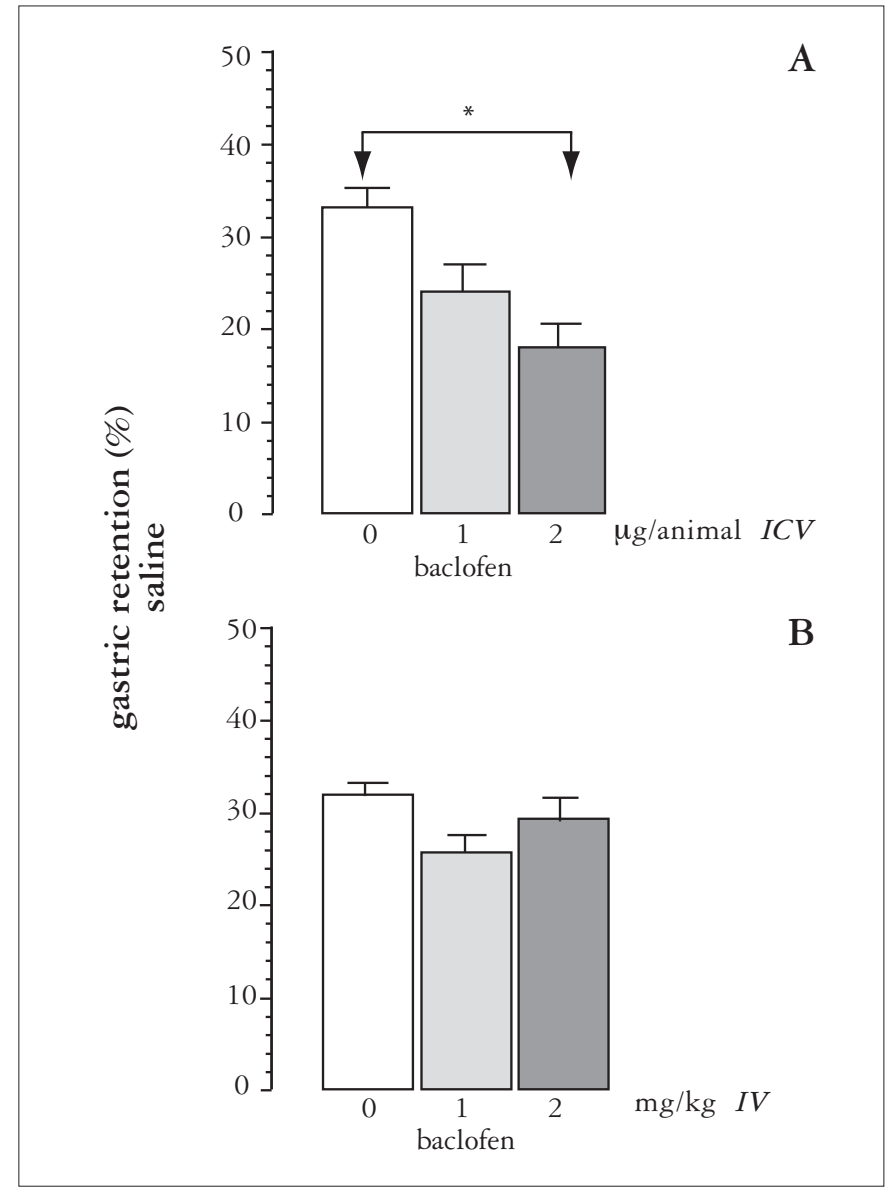

$*=P<0.05$ (Tukey test)

FIGURE 1. Gastric retention $(\%)$ as mean \pm SEM of a saline test meal, 10 min after administration by gavage to rats. A) Seven days before the experiment, a metal tube was implanted into the right lateral ventricle of the brain of the animals. Through an internal cannula, the animals received ICV $10 \mu \mathrm{L}$ of vehicle $(0)$ or an equal amount of a solution containing 1 or $2 \mu \mathrm{g}$ baclofen over a period of $30 \mathrm{~s}$, with the system remaining connected for an equal period of time. Gastric retention was evaluated $10 \mathrm{~min}$ after removal of the internal cannula $(\mathrm{n}=8)$. B) The animals received IV through a tail vein $1 \mathrm{~mL} / \mathrm{kg}$ vehicle $(0)$ or an equal amount of baclofen solution at the dose of 1 or $2 \mathrm{mg} / \mathrm{kg}$ and gastric retention was evaluated 10 min later $(n=8)$

\section{Solid test meal}

\section{Ingestion of ration}

There was no significant difference in ration ingestion among the animals that received ICV baclofen at the doses of 0,1 and $2 \mu \mathrm{g} / \mathrm{animal}$, with respective mean \pm SEM results of $580 \pm 61(n=7), 642 \pm 90(n=6)$ and $646 \pm 136(n=6)$ $\mathrm{mg} / 100 \mathrm{~g}$ animal weight.

Similarly, there was no significant difference in ration ingestion among the animals that received IV baclofen at the doses of 0,1 and $2 \mathrm{mg} / \mathrm{kg}(\mathrm{n}=7)$, with respective mean \pm SEM results of $1,122 \pm 112,1,001 \pm 124$ and $948 \pm 103$ $\mathrm{mg} / 100 \mathrm{~g}$ animal weight.

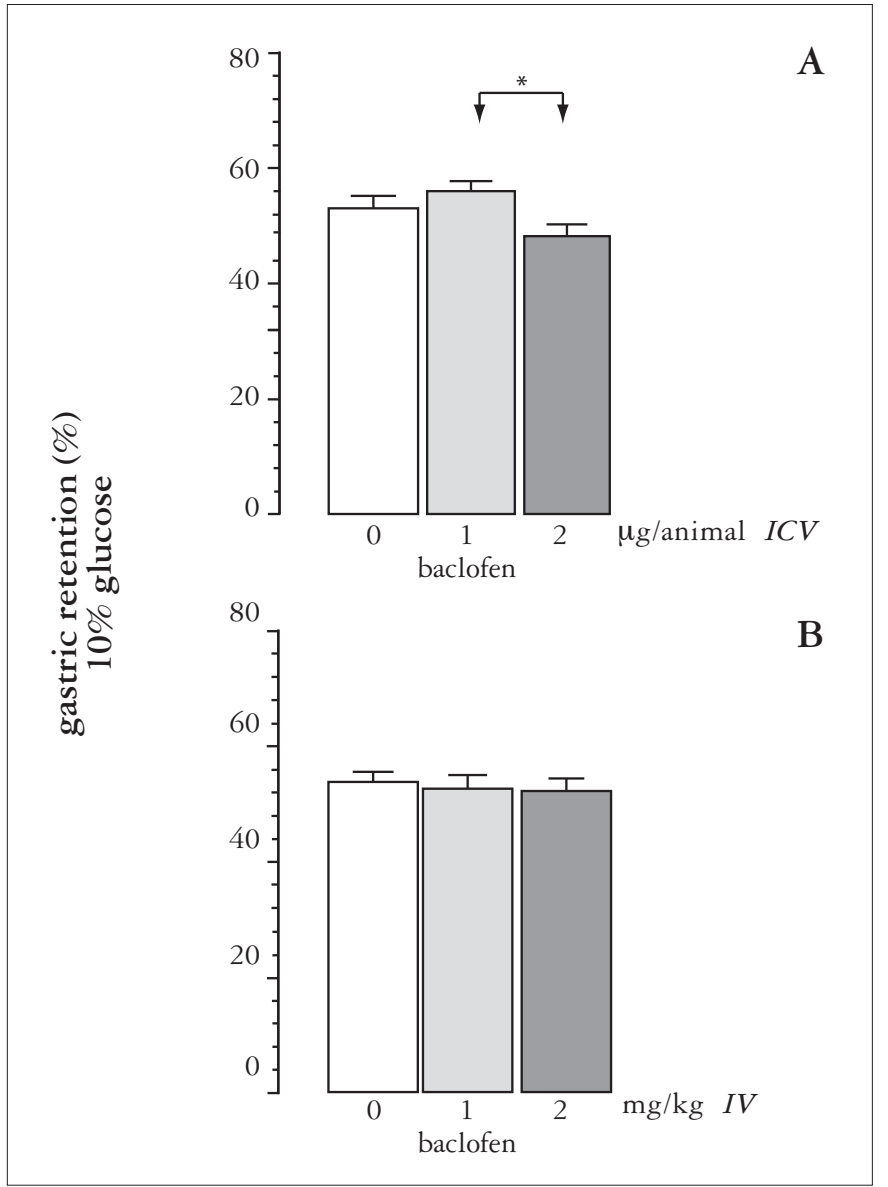

* $=P<0.05$ (Tukey test)

FIGURE 2. Gastric retention (\%) as mean \pm SEM of a $10 \%$ glucose test meal, $15 \mathrm{~min}$ after administration by gavage to rats. A) Seven days before the experiment, a metal tube was implanted into the right lateral ventricle of the brain of the animals. Through an internal cannula, the animals received ICV $10 \mu \mathrm{L}$ of vehicle (0) or an equal amount of a solution containing 1 or $2 \mu \mathrm{g}$ baclofen over a period of $30 \mathrm{~s}$, with the system remaining connected for an equal period of time. Gastric retention was evaluated 10 min after removal of the internal cannula $(n=8)$. B) The animals received IV through a tail vein $1 \mathrm{~mL} / \mathrm{kg}$ vehicle $(0)$ or an equal amount of baclofen solution at the dose of 1 or $2 \mathrm{mg} / \mathrm{kg}$ and gastric retention was evaluated 10 min later $(n=8)$

It should be pointed out that the animals treated ICV ingested less ration, i.e., approximately $60 \%$ of the amount ingested by the animals treated IV.

\section{Gastric emptying}

ICV administration of 1 or $2 \mu \mathrm{g}$ baclofen/animal (Figure 3A) significantly increased the GR of the solid test meal $(57.9 \pm 6.5 \%, \mathrm{n}=6$ and $66.6 \pm 6.3 \%, \mathrm{n}=6$, respectively) compared to control ( $35.1 \pm 4.4 \%, \mathrm{n}=7)$, indicating that this drug, when administered in the CNS, delays the GE of this test meal.

IV administration of $2 \mathrm{mg} / \mathrm{kg}$ baclofen (Figure 3B) significantly increased the GR $(71.9 \pm 2.6 \%, \mathrm{n}=7)$ of the solid test meal compared to control $(52.7 \pm 2.8 \%$, $(n=7)$. 
It is interesting to note that ICV control animals had a lower GR than IV control animals.

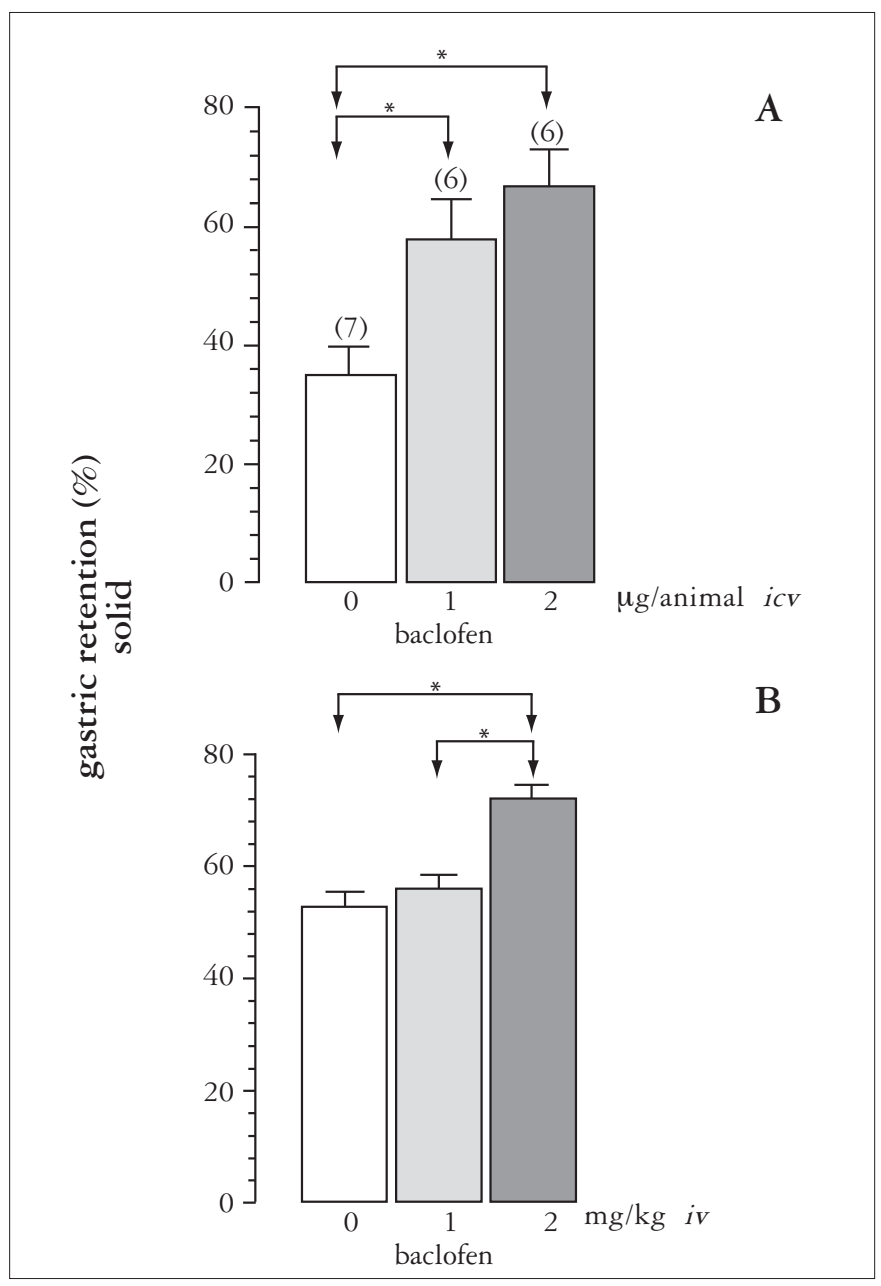

$*=P<0.05$ (Tukey tes)

FIGURE 3. Gastric retention (\%) as mean \pm SEM of the amounts of ration ingested (solid) by the animals over a period of $30 \mathrm{~min}, 2$ hours after the beginning of ingestion. A) Seven days before the test, a metal tube was implanted into the right lateral ventricle of the brain of the animals. Immediately after the end of the time of ration ingestion, the animals received ICV through an internal cannula $10 \mu \mathrm{L}$ of vehicle (0) or an equal amount of solution containing 1 or $2 \mu \mathrm{g}$ baclofen over a period of $30 \mathrm{~s}$, with the system remaining connected for an equal period of time. ()$=n$. B) Immediately after the end of the time of ration ingestion, the animals received IV through a tail vein $1 \mathrm{~mL} / \mathrm{kg}$ vehicle (0) or an equal amount of baclofen solution at the dose of 1 or $2 \mathrm{mg} / \mathrm{kg}(\mathrm{n}=7)$

\section{DISCUSSION}

The present results indicate that the racemic mixture of baclofen administered ICV ( $2 \mu \mathrm{g} /$ animal $)$ increased the GE of a non-caloric liquid saline test meal practically inert in its action on intestinal inhibitory receptors. The central effect of baclofen increasing GE would be expected due to its capacity of blocking in the DVC the mechanical inhibitory stimuli (gastric distention) transmitted by the afferent fibers of the vagus nerve $^{(1,7,8,30,31)}$. As a consequence there is an increase in the tonus of the proximal stomach leading to a faster GE of a saline test meal. The effect on gastric tonus is produced by the levo(-)-enantiomer of baclofen ${ }^{(1)}$.

Baclofen, a highly lipophilic compound, easily crosses the blood brain barrier ${ }^{(16)}$. The ICV dose $(\sim 8 \mu \mathrm{g} / \mathrm{kg})$, which significantly increased GE, was 250 times lower than the highest dose administered IV $(2000 \mu \mathrm{g} / \mathrm{kg})$. However, in the present study the same phenomenon was not observed with the IV doses, suggesting that an insufficient amount of the drug reached the DVC. Since baclofen also peripherally blocks the vagal afferent inhibitory stimuli triggered by the activation of tension receptors ${ }^{(4)}$, we may conclude that IV administration did not cause a peripheral blockade of these stimuli.

ICV or IV injection of baclofen had no effect on the GE of a $10 \%$ glucose solution compared to control (Figure $2 \mathrm{~A}$ and $\mathrm{B})$. The glucose solution is a caloric meal that, in contrast to saline, inhibits GE by stimulating intestinal receptors ${ }^{(33)}$. These results agree with information that baclofen, in the CNS or peripherally, does not interfere with the response of activation of chemosensitive receptors in the small intestine, such as those activated by cholecystokinin (CCK), which participates in the feedback regulation of emptying ${ }^{(31)}$. The data also agree with a study on healthy human adults which demonstrated that baclofen, during the postprandial period of a liquid caloric meal balanced with proteins, carbohydrates and fat, reduced the rate of transitory relaxation and increased the basal lower esophageal sphincter (LES) pressure compared to placebo. However, also compared to placebo, it did not change the reduced tonus and motility of the proximal stomach induced by the meal ${ }^{(25)}$. The activation of chemosensitive $\mathrm{CCK}_{1}$ and/or $5-\mathrm{HT}_{3}$ receptors by the lipid, protein and carbohydrate content of the meal is responsible for the intestinal inhibition of GE and for the development of satiety ${ }^{(17,20,33,34,35,37,41)}$. On this basis, these results in humans suggest that baclofen also does not interfere with the response of $5-\mathrm{HT}_{3}$ receptor activation.

However, we cannot rule out the possibility that, with higher baclofen doses or a lower glucose concentration in the solution, the tonus of the proximal stomach was such as to overcome the inhibitory power of the caloric content of the meal, causing a faster GE.

In the present study, although the reason why animals treated ICV consumed less ration is unknown, this event may be related to the surgical procedure from implantation of a tube in the lateral ventricle of the brain. In the control ICV animals, GE was faster than in the IV controls although the animals ingested a smaller amount of ration, a fact that may also have been related to the metabolic status of the animals after the surgical procedure. Apparently these facts do not invalidate the analysis of the effect of baclofen on the GE of solid food.

In view of this, it was observed that the administration of the drug ICV ( 1 and $2 \mu \mathrm{g} / \mathrm{animal})$ and IV $(2 \mathrm{mg} / \mathrm{kg}$ ) delayed the GE of the solid meal (Figure $3 \mathrm{~A}$ and $\mathrm{B}$ ). When baclofen was administered IV the delay of GE was observed only at the dose of $2 \mathrm{mg} / \mathrm{kg}$, suggesting that higher IV doses of the drug are necessary to reach CNS levels able to produce this effect. 
Since baclofen increases the amplitude and frequency of gastric contractions ${ }^{(1)}$ an increased GE of the solid meal would be expected, a fact that did not occur. Although the reason for this is unknown, two hypotheses may be raised to explain the phenomenon. The first is based on the fact that baclofen has been proposed as an effective drug for the treatment of gastroesophageal reflux disease (GERD) by its ability to inhibit the intermittent relaxation of the LES. This is the main physiopathological mechanism that determines this dysfunction, thus reducing, with the therapeutic use of baclofen, the reflux of stomach content to the esophagus in humans $s^{(11,22,23,26,48)}$. There is no information about the effect of baclofen on the pylorus. However, we may speculate that, if this drug interferes with the intermittent motor activity of this region, as described for the LES, the increased frequency or duration of pylorus contractions may compromise the GE of solids. A second hypothesis could be that the increased duodenal contractions induced by baclofen ${ }^{(16)}$, in opposition to its effect on the increase of gastric contraction ${ }^{(1)}$, would impair the GE of a solid meal such as that used in the present study. These hypotheses should be tested by means of experiments specifically planned for this purpose.

Our results differ substantially from those reported in the single experimental study conducted to assess the effect of baclofen on GE, which suggested that the drug delays liquid GE and accelerates solid GE. The methodology used in the cited study ${ }^{(40)}$ differed from ours in several aspects, as follows: 1) the animals used were mice; 2) baclofen was administered IP in a large volume of vehicle $(10 \mathrm{~mL} / \mathrm{kg}) ; 3)$ GE was evaluated by an indirect method by determining ${ }^{13} \mathrm{CO}^{2}$ in expired air, using ${ }^{13} \mathrm{C}$ loctanoic acid as a marker of the liquid and solid meals; 4) the caloric liquid meal used consisted of lipid; 5) the solid meal consisted of cooked egg yolk, which is easily fragmented; 6) in the evaluation of solid GE, baclofen was administered before the beginning of ingestion and it was not clear how much time the animals spent in the ingestion of this meal. Thus, it is impossible to compare the studies although in our case the results may be interpreted, in large part, according to the reported effects of baclofen on gastric motility.

The effect of baclofen on the GE of cow's milk was evaluated in a study on children with GERD ${ }^{(29)}$, but not in controls, and the authors concluded that the drug, in contrast to placebo, accelerated GE. However, many of the patients included in the study presented abnormal gastric motility which was "normalized" by baclofen. Thus, this effect may possibly have "improved" GE in these children with GERD. On the basis of this and of the above results, it is possible that baclofen at therapeutic doses does not alter the GE of a caloric liquid meal in control subjects.

In conclusion, in the present study baclofen administered 1. ICV $(2 \mu \mathrm{g} / \mathrm{animal})$, but not IV ( 1 and $2 \mathrm{mg} / \mathrm{kg})$ increased the GE of a non-caloric isotonic liquid test meal (saline); 2 . when administered ICV or IV, it had no effect on the GE of a $10 \%$ glucose solution; and 3. when administered ICV (1 and $2 \mu \mathrm{g} /$ animal) and IV $(2 \mathrm{mg} / \mathrm{kg})$ it delayed the GE of a solid meal.

Collares EF, Vinagre AM. Efeito do baclofen no esvaziamento gástrico de líquido e de sólido em ratos. Arq Gastroenterol. 2010;47(3)290-6.

RESUMO - Contexto - O ácido gama-aminobutírico (GABA) é um potente neurotransmissor inibitório. Há evidências que receptores GABAB localizados no complexo dorsal do vago e em fibras aferentes do nervo vago participam no controle da motricidade gastrointestinal. Objetivo - Avaliar o efeito intracerebroventricular (ICV) e intravenoso (IV) do baclofen, um agonista para receptores $\mathrm{GABA}_{\mathrm{B}}$, sobre o esvaziamento gástrico de líquidos e de sólidos em ratos. Métodos - Foram utilizados ratos adultos Wistar, machos, de 250-300 g (n = 6-8 animais). O esvaziamento gástrico das refeições de prova líquidas, marcadas com fenol vermelho, foi avaliado através da determinação da \% de retenção gástrica, 10 e 15 min após administração orogástrica das refeições salina e de glicose a 10\%, respectivamente. As injeções ICV de baclofen (1 e $2 \mu \mathrm{g} / \mathrm{animal}$ ) foram feitas através de uma sonda implantada no ventrículo lateral do cérebro e as injeções IV de baclofen $(1$ e $2 \mathrm{mg} / \mathrm{kg}$ ) numa veia da cauda. O esvaziamento gástrico das refeições de prova líquidas foi determinado 10 ou 30 min após a administração de baclofen ICV ou IV, respectivamente. O esvaziamento gástrico da refeição sólida foi avaliado através da determinação da \% de retenção gástrica $2 \mathrm{~h}$ após o início da ingestão da ração habitual do animal, ingerida durante $30 \mathrm{~min}$. As administrações de baclofen ICV (1 e $2 \mu \mathrm{g} / \mathrm{animal})$ e IV (1 e $2 \mathrm{mg} / \mathrm{kg}$ ) foram feitas imediatamente após o término da ingestão da refeição sólida. Os grupos controles receberam ICV ou IV veículo (solução salina estéril). Resultados - O grupo de animais que recebeu baclofen $2 \mu \mathrm{g} / \mathrm{animal}$ ICV apresentou retenção gástrica (média \pm SEM) de salina $(18.1 \pm 2.5 \%)$ significantemente menor $(P<0.05$, teste de Tukey) em relação ao grupo controle $(33.2 \pm 2.2 \%)$. No grupo com administração IV da droga, a retenção gástrica da mesma refeição de prova não diferiu do seu controle. As administrações ICV e IV de baclofen não tiveram qualquer efeito no esvaziamento gástrico da solução de glicose a $10 \%$, em relação aos seus controles. A administração ICV de 1 ou $2 \mu \mathrm{g} /$ animal de baclofen aumentou significativamente as retenções gástricas da refeição de prova sólida (57.9 $\pm 6.5 \%$ e $66.6 \pm 6.3 \%$, respectivamente) em relação ao grupo controle $(35.1 \pm 4.4 \%)$. O mesmo fenômeno somente foi observado com a dose IV de $2 \mathrm{mg} / \mathrm{kg}$ $(71.9 \pm 2.6 \%)$ em relação ao grupo controle $(52.7 \pm 2.8 \%)$. Conclusões - O baclofen administrado: 1 . ICV ( $2 \mu \mathrm{g} / \mathrm{animal})$, mas não IV, aumentou o esvaziamento gástrico de uma refeição de prova líquida isotônica não-calórica (salina); 2. ICV ou IV, não teve efeito sobre o esvaziamento da solução de glicose a 10\%; 3) ICV (1 e $2 \mu \mathrm{g} /$ animal) e IV ( $2 \mathrm{mg} / \mathrm{kg}$ ) retardou o esvaziamento gástrico da refeição sólida.

DESCRITORES - Esvaziamento gástrico. Baclofeno. Ratos. 


\section{REFERENCES}

1. Andrews PLR, Wood KL. Systemic baclofen stimulates gastric motility and secretion via a central action in the rat. Br J Pharmacol. 1986;89:461-7.

2. Azpiroz F. Control of gastric emptying by gastric tone. Dig Dis Sci. 1994;39:18s9s.

3. Bertolino M, Kellar KJ, Vicini S, Gillis RA. Nicotinic receptor mediates spontaneou GABA release in the rat dorsal motor nucleus of the vagus. Neuroscience. 1997;79:671-81.

4. Blackshaw LA. Receptors and transmission in brain-gut axis: potential for nove therapies. IV. GABA(B) receptors in the brain- gastroesophageal axis. Am J Physiol Gastrointest Liver Physiol. 2001;281:G311-5.

5. Bormann J. The 'ABC' of GABA receptors. Trends Pharmacol Sci. 2000;21:16-9.

6. Bowery NG. GABAB receptor pharmacology. Annu Rev Pharmacol. Toxicol 1993;33:109-47.

7. Brooks PA, Glaum SR, Miller RJ, Spyer KM. The actions of baclofen on neurones and synaptic transmission in the nucleus tractus solitarii of the rat in vitro. $\mathrm{J}$ Physiol. 1992;457:115-29.

8. Browning KN, Travagli RA. Mechanism of action of baclofen in rat dorsal moto nucleus of vagus. Am J Physiol Gastrointest Liver Physiol. 2001;280:G1106-13.

9. Bucaretchi F, Collares EF. Effect of Phoneutria nigriventer spider venom on gastric emptying in rats. Braz J Med Biol Res. 1996;29:205-11.

10. Bustorff-Silva J, Perez CA, Fonkalsrud EW, Hoh C, Raybould HE. Gastric emptying after fundoplication is dependent on changes in gastric volume and compliance. J Pediatr Surg. 1999;34:1232-5.

11. Ciccaglione AF, Marzio L. Effect of acute and chronic administration of the GABAB agonist baclofen on 24 hour $\mathrm{pH}$ metry and symptoms in control subjects and in patients with gastro-oesophageal reflux disease. Gut. 2003;52:464-70

12. Collares EF, Vinagre AM. Effect of the GABAB agonist baclofen on dipyroneinduced delayed gastric emptying in rats. Braz J Med Biol Res. 2005;38:99-104.

13. Couve A, Moss SJ, Pangalos MN. GABAB receptors: a new paradigm in G protein signaling. Mol Cell Neurosci. 2000;16:296-312.

14. Cryan JF, Kaupmann K. Don't worry 'B' happy!: a role for GABA(B) receptors in anxiety and depression. Trends Pharmacol Sci. 2005;26:36-43.

15. Ehrlein HJ, Akkermans LMA. Gastric emptying. In: Akkermans LMA, Johnson AG, Read NW, editors. Gastric and gastroduodenal motility. New York: Praeger; c1984. p.74-84

16. Fargeas MJ, Fioramonti J, Bueno L. Central and peripheral action of GABAA and GABAB agonists on small intestine motility in rats. Eur J Pharmacol. 1988;150:163-9.

17. Gershon MD. Review article: serotonin receptors and transporters - roles in norma and abnormal gastrointestinal motility. Aliment Pharmacol Ther. 2004;20:3-14.

18. Goto Y, Tache Y, Debas H, Novin D. Gastric acid and vagus nerve response to GABA agonist baclofen. Life Sci. 1985;36:2471-5.

19. Greenwood-Van Meerveld B, Barron KW. Tonic GABA(A) receptor-mediated neurotransmission in the dorsal vagal complex regulates intestinal motility in rats. Eur J Pharmacol. 1998;346:197-202.

20. Johnson LR. Peptides of gastrointestinal tract. In: Johnson LR, editor. Physiology of gastrointestinal tract. 5th ed. St. Louis: Mosby;1997. p.1-14.

21. Johnston GAR. GABAc receptors: relatively simple transmitter-gated ion channels? Trends Pharmacol Sci. 1996;17:319-23.

22. Kawai M, Kawahara H, Hirayama S, Yoshimura N, Ida S. Effect of baclofen on emesis and 24-hour esophageal $\mathrm{pH}$ in neurologically impaired children with gastroesophageal reflux disease. J Pediatr Gastroenterol Nutr. 2004;38:317-23.

23. Koek GH, Sifrim D, Lerut T, Janssens J Tack J. Effect of GABA(B) agonis baclofen in patients with symptoms and duodeno-gastro-oesophageal reflux refractory to proton pump inhibitors. Gut. 2003;52:1397-402.

24. Langhans W, Harlacher R, Balkowski G, Scharrer E. Comparison of the effect of bacterial lipopolysaccharide and muramyl dipeptide on food intake. Physiol Behav. 1990;47:805-13.

25. Lee KJ, Vos R, Janssens J, Tack J. Differential effects of baclofen on lowe oesophageal sphincter pressure and proximal gastric motility in humans. Aliment Pharmacol Ther. 2003;18:199-207.
26. Lidums I, Lehmann A, Checklin H, Dent J, Holloway RH. Control of transient lower esophageal sphincter relaxations and reflux by the GABA(B) agonist baclofen in normal subjects. Gastroenterology. 2000;118:7-13.

27. Misgeld U, Bijak M, Jarolimek W. A Physiological role for GABAB receptors and the effects of baclofen in the mammalian central nervous system. Prog Neurobiol. 1995;46:423-62.

28. Mody I, De Koninck Y, Otis TS, Soltesz I. Bridging the cleft at GABA synapses in the brain. Trends Neurosci. 1994;17:517-25.

29. Omari TI, Benninga MA, Sansom L, Butler RN, Dent J, Davidson GP. Effect of baclofen on esophagogastric motility and gastroesophageal reflux in children with gastroesophageal reflux disease: a randomized controlled trial. J Pediatr. 2006;149:468-74.

30. Page AJ, Blackshaw LA. GABA(B) receptors inhibit mechanosensitivity of primary afferent endings. J Neurosci. 1999; 19:8597-602.

31. Partosoedarso ER, Young RL, Blackshaw LA. GABA(B) receptors on vaga afferent pathways: peripheral and central inhibition. Am J Physiol Gastrointest Liver Physiol. 2001;280:G658-68

32. Pratt GD, Bowery NG. Autoradigraphy of GABA receptor binding sites in the dorsal vagal complex of the rat hindbrain [abstract]. Brit J Pharmacol. 1992;107(Suppl):211P.

33. Raybould HE, Lloyd KCK. Integration of postprandial function in the proximal gastrointestinal tract. Role of CCK and sensory pathways. Ann N Y Acad Sci. 1994; 713:143-56

34. Raybould HE, Glatzle J, Robin C, Meyer JH, Phan T, Wong H, Sternini C. Expression of $5-\mathrm{HT}_{3}$ receptors by extrinsic duodenal afferents contribute to intestinal inhibition of gastric emptying. Am J Physiol Gastrointest Liver Physiol. 2003;284:G367-72.

35. Raybould HE. Mechanisms of CCK signaling from gut to brain. Curr Opin Pharmacol. 2007:7:570-4

36. Rigato SZP. Estudo do esvaziamento gástrico na insuficiência renal crônica moderada em ratos [tese]. Campinas: Faculdade de Ciências Médicas da Universidade Estadual de Campinas; 1996.

37. Savastano DM, Covasa M. Intestinal nutrients elicit satiation through concomitant activation of $\mathrm{CCK}_{1}$ and $5 \mathrm{HT}_{3}$ receptors. Physiol Behav. 2007;92:434-42.

38. Sivarao DV, Krowicki ZK, Hornby PJ. Role of GABA receptors in rat hindbrain nuclei controlling gastric motor function. Neurogastroenterol Motil. 1998;10:30513.

39. Soares ACF, Vinagre AM, Collares EF. Effect of antipyrine on the gastric emptying of liquid in rats. Braz J Med Biol Res 2006; 39:1507-12.

40. Symonds E, Butler R, Omari T. The effect of GABA receptor agonist baclofen on liquid and solid gastric emptying in mice. Eur J Pharmacol. 2003;470:95-7.

41. Tomé D. From gut nutrient sensing to nutrient perception: a cooperative role involving CCK and 5-HT? Am J Physiol Regul Integr Comp Physiol. 2007;292:R1061-2.

42. Vinagre AM, Collares EF. Effect of the 4-aminoantipyrine on gastric compliance and liquid emptying in rats. Braz J Med Biol Res. 2007;40:903-9.

43. Weisbrodt NW. Basic control mechanisms. In: Akkermans LMA, Johnson AG, Read NW, editors. Gastric and gastroduodenal motility. New York: Praeger; c1984. p.3-20.

44. Weisbrodt NW. Gastric emptying. In: Johnson LR, editor. Gastrointestina physiology. 5th ed. St Louis: Mosby; 1997. p.33-42.

45. Wood JD, Alpers DH, Andrews PLR. Fundamentals of neurogastroenterology. Gut. 1999;45:II6-II16.

46. Yuan C-S, Liu D, Attele AS. GABAergic effects on nucleus tractus solitarius neurons receinving gastric vagal inputs. J Pharmacol Exp Ther. 1998;286:736-41.

47. Zarrindast MR, Hosseini-Nia T, Allah-Maddadi S. Food intake suppressant effect of baclofen in rats. Gen Pharmacol. 1989;20:701-3.

48. Zhang Q, Lehmann A, Rigda R, Dent J, Holloway RH. Control of transient lower oesophageal sphincter relaxations and reflux by the GABAB agonist baclofen in patiens with gatro-oesophageal reflux disease. Gut. 2002;50:19-24.

Received 17/4/2009.

Accepted 6/5/2009 